constant character in the antelopes, as differentiating various subgenera or natural groups.

If any philosophical thinker can explain what is the vera causa which has provided for the Cainotherium and Guanaco deep preorbital interspaces, whilst in their congeners the Dorcatherium and Vicuña, no such interspace exists, a character originally pointed out by Dr. J. E. Gray, and which according to my experience is the sole specific difference which can be demonstrated, such explanation will be of great benefit to zoological science. The above observations are made solely with a view of suggesting further inquiry on this most interesting topic. I trust that some of those writers who have so carefully studied the osteology of Ruminautia, may be led to reconsider the question, and to make further observations on the function of the facial interspaces in both recent and fossil ruminants.

It bas been suggested to me, that the two boles in the Microtherium skull, as they are undoubtedly asymmetrical, might have been produced artificially or accidentally, the bone at this place being exceedingly thin. Should such a theory be proved correct, the Microtherium of the Auvergne deposit would still find its nearest analogue in the existing Meminna of Ceylon, and by the demonstration of this affinity, still further corroborate the truth of Professor Owen's generalization,--"The affinity of the Microtheres to the Cheorotains is nevertheless very close" (Palæontology, 2nd ed. p. 372).

\title{
ON THE DISCOVERY OF HUMAN AND ANLMAL BONES IN HEATHERY BURN CAVE, NEAR STANHOPE.
}

\section{Br Johr Elliott, Esq.}

In a tolerably deep ravine, surrounded by trees and brushwood growing in wild profusion, was, until lately, a cave, in that member of the carboniferous formation locally called the "Great Limestone," and situated about one mile and a quarter north from the town of Stanhope, in the county of Durham. The limestone is now being worked for the purpose of supplying the Weardale Iron Company with a flux used in the operation of smelting their ironstone; and consequently the cave has been laid bare to the light of day.

The cave was much visited a few years ago, both by strangers and persons living in the locality, but probably few of the visitors ever studied the excavating forces by means of which the cave was hollowed out of the solid limestone, and fewer still, if any, would think that they were treading on a primeval burial-place.

Doubtless the excavation must be mainly due to aqueous agency, but a reference to Sir Charles Lyell's 'Principles of Geology,' Professor Phillips's 'Treatise on Geology,' and Richardson's 'Geology,' shows that our leading writers on this subject consider that the first 
cause of a cavern must have been a fracture in the limestone rock, consequent on the upheaval of the strata, and that water then finding access to the crack, would wear it nut to its present dimensions.

Fractures in this case would most probably take place when the "Red Vein" was formed, which is only between two hundred and

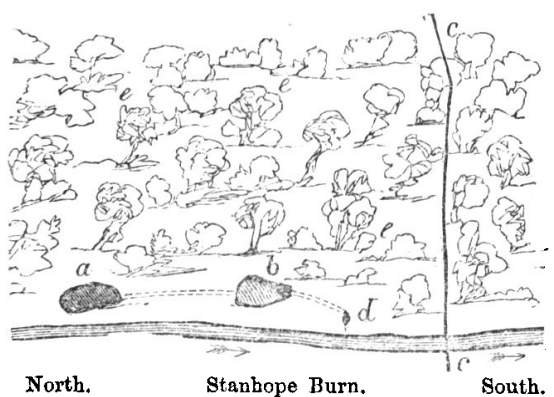

Fig. 1.-Ground plan of cavern district.

$a$ Mouth of Cave. $b$ Bone Deposit. $c$ Red Vein. $d$ Where the water issues from the cave. $e$ e Trees and brushwood before the quarry was worked, on hill-side; angle of slope 45 degrees.

crease the probability of an original fissure.

The cave must be very old if we suppose it to have been formed by the water running down the ravine when on a level with its

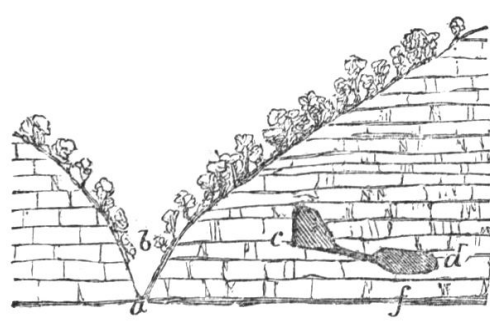

Fig. 2.-Transverse section of cave. moutb or opening, seeing that the watercourse is now worn down ten or twelve feet below the cave's bottom. Again, if we suppose it to have been excavated by the attrition of the waves of the sea during some remote period, when the waters of the ocean stood on a level with the cave, it must still have a very ancient origin, for the cave is

$a$ Level of the Burn. $b$ Level of cave (from $a$ to situated upwards of thirty miles

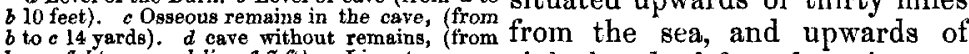
base of $d$ to ground-line $f$ ft). $e$ Limestone. eight hundred feet above its present level. This locality must have been submerged during the glacial period, as we have evidence of by the deposits of boulder clay; and if the sea on receding should have remained on a level with the limestone for a great length of time, the result would have been the wearing down of the rock, or the hollowing out of crevices and caves in the exposed strata.

In a certain place of the cave-flooring, the workmen recently came upon a large sheet of stalagmite of varying thickness, but averaging about four inches. This calcareous incrustation has been formed by the ceaseless dropping of water holding lime in solution, from the roof of the care. Un removing this crust and a small portion of fine 
sand and silt, the workmen exhumed a human skull and a quantity of bones, some undoubtedly human, and others belonging to the lower animals. The human skull, according to its phrenological development, seems to indicate a low intellectual capacity, the forehead being low, and the circumference under the average standard. There

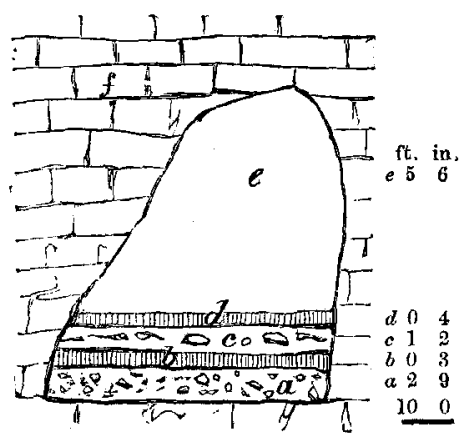

[6 or 7 feet wide.]

Fig. 3.-Section of care.

a Angular piece of Limestone, Sand, ete. Stalagnite. $c$ Osseous remains, Sand, Silt, etc. $d$ Stalagmite, $e$ Open cave. $f$ Limestone. is also a fragment of a skull which seems to have belonged to a tolerably large animal, as it measures three and a quarter inches from the medial line to the outside beside the ear, giving a breadth of six and a half inches for the whole skull; then if the integuments, hair, etc. be added, we should have a physiognomy little short of nine inches wide, and this creature may have been that of one of the principal tenants of the cave, and which probably devoured the others. Inter. mixed with the remains are very small pieces of bone, etc., partially cemented together by calcareous matter, and occurring in patches $s t$ different places; these have the appearance of coprolites. The bones are nearly all fragmentary, and much broken; the fractures being of an ancient date, thereby showing that the remains had been subject to violence and fracture before they were imbedded in their calcareous tomb.

How long these remains have lain in the cave? by what means they have been carried and entombed there? whether the animal-remains belong to existing or to extinct species? and how the fractured bones are to be accounted for? are all very interesting palæontological problems.

The cave has in all probability bcen occasionally inhabited by wolves, foxes, etc., which would sally forth, seize their prey, and return to devour it, leaving the bones to be covered over by the stalagmite as we find them ; the coprolites before mentioned seem to point to this conclusion. There seems to be not so much mystery about the animal bones being found there; but the case is quite different as regards the human. There is always something strange and startling in such occurrences, when human remains are found otherwise than reposing in the silent and hallowed precincts of a regular burying-place.

During the interment of these relics of some of the perhaps earliest members of our race, the rippling of running water on the cavern floor, the monotonous drippings from the roof, the growling perhaps of wolves, or the barking of foxes, and the bellowing of the wind through the gloomy chambers of the cavern, would form the only requiem. 
It ought, in conclusion, to be observed, that the remains are deposited in a certain wing or chamber of the cave, about two feet above the floor where the water runs, so that they would lie dry, with the exception of the calcareous droppings from the roof, or in the case of the caveru water being swollen above the capacity of the lower channel to contain it.

Although a considerable portion of the cave bas been destroyed by the quarrying operations, which are still going on, there remains yet a much larger extent undisturbed, so that more remains will most likely be discovered.

\section{West Croft, Stanhope, by Darlington.} Dec. $17 t h, 1861$.

[These bones, with specimens of the stalagmite, etc., have been transmitted to us and will receive careful study and consideration. We shall shortly give a concise and accurate account of them.-Eo. Gkor., 22 Dec. 1861.j

\section{PROCEEDINGS OF GEOLOGICAL SOCIETIES.}

Geologicat Societr of London.-December 4.-Sir R. I. Murchison, V.P.G.S., in the chair. The following communication was read:- "On the Bracklesham Beds of the Isle of Wight Basin." By the Rev. O. Fisher, M.A., F.G.S. After noticing the researches of Prestwich and Dixon, the author proceeded to state that most of the "Bracklesham beds" are displayed at low water at Bracklesham Bay; but other and higher beds belonging to the same series are to be observed in the New Forest, at Stubbington, and in the Isle of Wight. By means of the fossils, for the most part, Mr. Fisher divides the series into four groups :1. The uppermost abounds in Gasteropoda, and has several fossil-beds. One of these, in the eastern part of its range, is full of Nummulina variolaria (No. 16 of Mr. Prestwich's Section of Whitecliff Bay, Quart. Journ. Geol. Soc. vol. ii. pl. 9) ; the $N$. variolaria bed of Selsea and of Stubbington; and the Shepherd's Gutter bed at Bramshaw, New Forest. The beds above the last-named are-1st, a portion of No. 19 of the Whitecliff Bay section and the coral-bed of Stokes Bay and Hunting Bridge (New Forest); and 2nd, the shell-bed at Hunting Bridge, and pebble-bed, with shell-casts, at Highcliff. The lowest bed of this groupis the "Cypræa-bed" of Selsea, the "Cardita-bed" of Stubbington, and the Brook bed in the New Forest. 2. This group is more sandy than the last; it has two fossil-beds, one of which contains Cerithium giganteum (at Hillhead, Stubbington; and half a mile west of Thorney station, Bracklesham Bay). 3. This is a sandy group, and is remarkable for the profusion of Nummulina levigata in its principal fossil-bearing beds. 4. This embraces the lowest fossiliferous sands of Bracklesham Bay. Its distinctive shells are Cardita acuticosta and Cypraa tuberculosa. Some species of mollusks pass upwards from the Bracklesham into the Barton series; yet the Fanna of the Bracklesham beds has a sufficiently distinct facies; and the following species range through this series, and are confined to it-Cardita planicosta, Sanguinolaria Hollowaysii, Solen obliquus, Cytherea suberycinoides, Voluta Cithara, and Turritella sulcifera. Pecten corneus is also characteristic, but is met with higher up. 